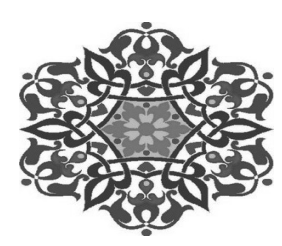

\title{
Kedudukan Akal dalam al-Qur'an dan al-Hadis
}

\author{
Aan Rukmana \\ Dosen Falsafah dan Agama Universitas Paramadina \\ Email: aanrukmana@gmail.com \\ HP 08121887988
}

\begin{abstract}
Abstrak: Di dalam Islam terdapat dua sumber referensi yaitu alQur'an dan al-Hadis. Kedua referensi tersebut menjadi pegangan bagi umat Islam di dalam pembentukan hukum yang sesuai dengan syariat Islam. Al-Qur'an sendiri sangat fokus terhadap persoalan intelek/akal di dalam Islam. Semangat tersebut pernah melahirkan peradaban luhur masyarakat Islam. Sejalan dengan itu, Hadis juga memainkan peranan penting dalam rangka mempromosikan keutamaan intelek/kemampuan dalam mendukung kehidupan kita sehari-hari. Artikel ini mencoba untuk memperdalam keutamaan penggunaan inetelek ditinjau dari perspektif al-Qur'an dan al-Hadis.
\end{abstract}

Kata Kunci: akal, hadis, takhrij al-hadith, matn, sanad

\section{A. Pendahuluan}

Agama Islam merupakan agama terakhir yang memiliki ajaran yang sangat lengkap. Ajaran tersebut meliputi kehidupan individu, masyarakat, tata cara bernegara yang baik sampai kepada persoalan yang menyangkut ekonomi, politik dan lain sebagainya. Maka tidak heran jika dalam sejarahnya, Islam pernah menduduki posisi yang sangat penting dalam memperkenalkan peradaban yang kosmopolitan kepada bangsa-bangsa yang lainnya. Pernah pada masanya, Islam begitu jaya, mulai dari perpolitikan sampai kepada persoalan kemajuan ilmu pengetahuan dan teknologi.

Terkait kemajuan ilmu pengetahuan dan teknologi ini, kita mengenal banyak ilmuwan-ilmuwan besar Islam yang tampil sambil menorehkan prestasi mengagumkan dan pengaruhnya sampai menembus lintas daerah, agama dan lain sebagainya. Tokoh-tokoh besar seperti al-Kindi, al-Farabi, Ibn Sina, al-Thusi 
dan lain sebagainya turut mewarnai peradaban Islam dengan tinta emas yang terbaik. Di bidang agama sendiri, muncul tokoh-tokoh besar seperti Imam al-Syafii, Imam Ghozali dan lain sebagainya, belum lagi lahirnya ulama-ulama ahli tafsir seperti al-Thabari, al-Qurthubi dan yang lainnya serta ulama-ulama hadits (rijal al-hadits) seperti Imam Bukhari, Imam Muslim dan lain-lainnya. Semua pencapaian itu tentu tidak datang dengan sendirinya, melainkan disebabkan oleh ajaran al-Qur'an dan al-Hadits itu sendiri yang memang menjunjung tinggi ilmu pengetahuan.

Al-Qur'an dan al-Hadis merupakan pegangan utama umat Islam. Hal tersebut senada dengan Hadits Nabi SAW bahwa barang siapa yang berpegang teguh dengan keduanya maka tidak akan tersesat selamanya. Berikut bunyi hadits Nabi Muhammad SAW sebagaimana diriwayatkan oleh Muslim, Abu Daud dan Ibn Majah:

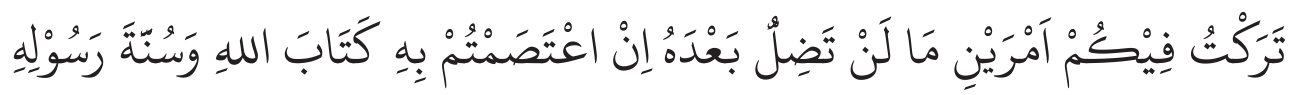

"Telah aku tinggalkan untuk kalian dua perkara dimana kalian tidak akan tersesat selamanya yaitu al-Qur'an dan Sunnah Rasulullah"I

Dari hadis tersebut nampak jelas bahwa posisi al-Qur'an dan al-Hadis memiliki peran yang teramat penting dalam mendorong umat Islam untuk maju jauh melampaui umat-umat yang lainnya. Anjuran al-Qur'an kepada umat Islam untuk melakukan "Iqra!" telah mendorong terjadinya revolusi pemikiran di dalam masyarakat Islam yang sebelumnya terbelakang dan tertinggal menjadi umat yang berada pada garis terdepan peradaban. ${ }^{2}$

Di antara sekian ajaran al-Qur'an dan al-Hadis yang paling fenomenal yaitu anjurannya untuk umat Islam dalam memaksimalkan akal. Dampak dari anjuran ini umat Islam mulai memikirkan alam semesta dengan segenap isinya yang akibatnya ilmu pengetahuan berkembang sangat pesat. Jika kita merujuk kepada al-Qur'an, maka akan mudah kita jumpai ayat-ayat al-Qur'an yang memerintahkan kita untuk berpikir dan menggunakan akal sampai-sampai perkataan la'allakum ta’qilun, la'allakum tatadabarun, la'allakum tatafakkarun sering

${ }^{1}$ Dalam hadits lain dengan redaksi yang sedikit berbeda berbunyi:

$$
\text { تركت فيكم أمرين لن تضلوا ما تمسكتم بهما كتاب اللهب وسنة نبيه }
$$

Saya telah meninggalkan dua pusaka, jika keduanya kalian berpegang teguh kepadanya, maka sekali kali tidak akan tersesat selamanya yaitu al-Qur'an dan Hadis. Dapat dilihat dalam Imam Muslim (Beirut: Dar Ihya al-Turath al-Arabi, T.tp), vol 2, hal, 886. Lihat pula Ibn Majah, Sunan Ibn Majah (Beirut: Dar Ihya al-Kutub al-Arabi, T,tp), vol, 2, hal, 1022. 2003, hal. 36

${ }^{2}$ Seyyed Hossein Nasr \& Oliver Leaman (ed.). Ensiklopedi Filsafat Islam. Bandung: Mizan, 
kita jumpai di dalam al-Qur'an. Al-Qur'an juga mengapresiasi dengan sangat tinggi orang-orang yang berilmu bahkan berjanji untuk mengangkat mereka beberapa derajat:

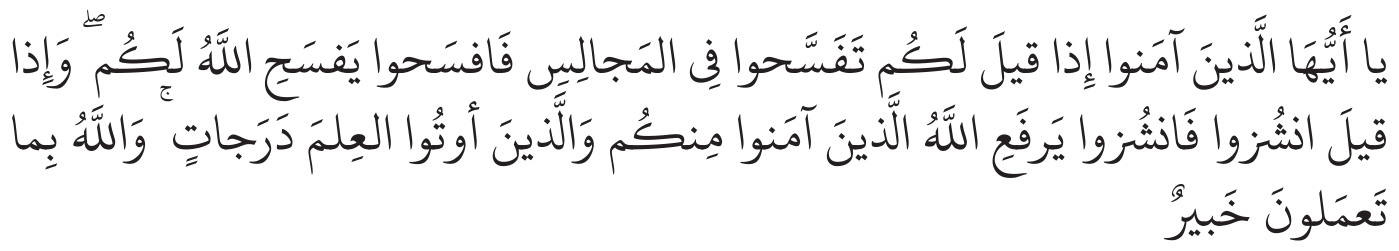

Hai orang-orang beriman apabila dikatakan kepadamu: "Berlapang-lapanglah dalam majlis", maka lapangkanlah niscaya Allah akan memberi kelapangan untukmu. Dan apabila dikatakan: "Berdirilah kamu”, maka berdirilah, niscaya Allah akan meninggikan orang-orang yang beriman di antaramu dan orang-orang yang diberi ilmu pengetahuan beberapa derajat. Dan Allah Maha Mengetahui apa yang kamu kerjakan.(Q.S. Al-Mujadilah: 11).

Hal yang sama terdapat juga di dalam Hadis, bagaimana Nabi Muhammad mendorong umat Islam, seperti hadits terlampir:

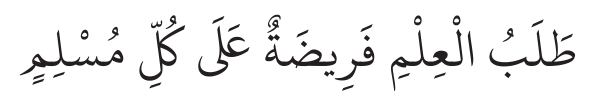

"menuntut ilmu itu wajib bagi setiap muslim" (H.R. al-Baihaqi). ${ }^{3}$

\section{B. Posisi Akal di dalam al-Qur'an}

Di dalam al-Qur'an, sebagaimana sempat diulas sedikit di awal tulisan ini, menduduki posisi yang sentral. Akal merupakan anugerah terbesar yang diberikan Allah SWT kepada umat manusia. Dengan akal-lah mereka dapat membedakan baik dan benar serta dapat menuntun mereka untuk hidup bermartabat. Menurut Muhammad Abduh, manusia diberikan berbagai jenis hidayah oleh Allah SWT yang meliputi: ${ }^{4}$

${ }^{3}$ Diriwayatkan pula dari Ibn Majah. Lihat Ibn Majah, Sunan Ibn Majah (Sunan Ibn Majah (Beirut: Dar Ihya al-Kutub al-Arabi, T,tp), vol 1, hal, 81. Bahkan Nabi saw menempatkan akal sebagai identitas orang yang beriman

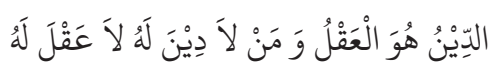

ginya."

"Agama itu adalah akal, dan seseorang itu tiada agama baginya yang tidak ada akal ba-

${ }^{4}$ HM Rasjidi dan H. Harifuddin Cawidu. Islam untuk Disiplin Ilmu Filsafat (Jakarta: Bulan Bintang, 1988), hal, 19. 
1. Hidayah Instink (gharizah)

2. Hidayah Indera dan Perasaan

3. Hidayah Akal

4. Hidayah Agama (din)

5. Hidayah Taufik ('Inayah)

Dari kelima hidayah tersebut, satu di antaranya yaitu hidayah akal. Jadi menurut Abduh, akal merupakan hidayah dari Allah SWT dan ini sejalan dengan ayat-ayat al-Qur'an.

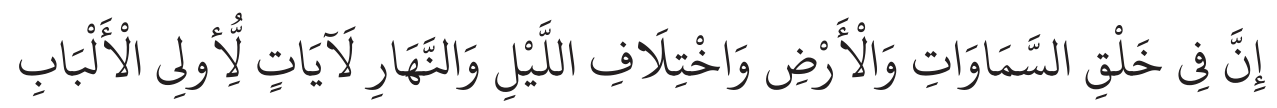

"Sesungguhnya dalam penciptaan langit dan bumi, dan silih bergantinya malam dan siang terdapat tanda-tanda bagi orang-orang yang berakal" (QS Ali 'Imran) [3] 190).

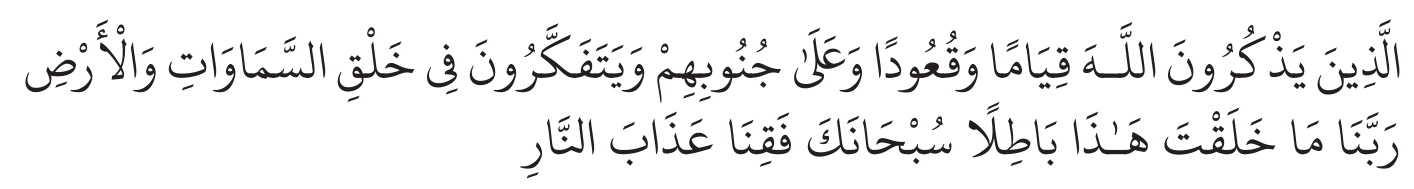

"(yaitu) orang-orang yang mengingat Allah sambil berdiri atau duduk atau dalam keadan berbaring dan mereka memikirkan tentang penciptaan langit dan bumi (seraya berkata): "Ya Tuhan kami, tiadalah Engkau menciptakan ini dengan sia-sia, Maha Suci Engkau, maka peliharalah kami dari siksa neraka.” (QS Ali 'Imran) [3] 191).

Dari kedua ayat tersebut, nampak jelas bahwa orang-orang yang berakal akan senantiasa menjadi hamba-hamba yang saleh. Mereka senantiasa berpikir tentang alam semeseta untuk menyingkap rahasia ilahi di dalamnya. Orangorang yang berakal senantiasa mereka akan terus berpikir tentang Allah baik ketika berjalan maupun ketika melakukan aktivitas yang lainnya sebagaimana bunyi ayat terlampir:

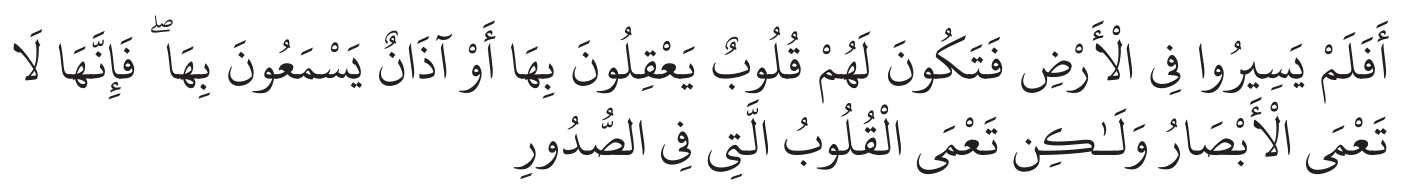

${ }^{5}$ HM Rasjidi dan Drs. H. Harifuddin Cawidu. Islam untuk Disiplin Ilmu Filsafat, hal, 20. 
"maka apakah mereka tidak berjalan di muka bumi, lalu mereka mempunyai hati yang dengan itu mereka dapat memahami atau mempunyai telinga yang dengan itu mereka dapat mendengar? Karena sesungguhnya bukanlah mata itu yang buta, tetapi yang buta, ialah hati yang di dalam dada." (QS al-Hajj [22] 46).

Allah pun mempertanyakan dan menantang umat manusia untuk berpikir dan menjadikan merefleksikan apa-apa yang terjadi di langit dan bumi. Dengan berpikir mengenai bumi dan segala isinya manusia sebenarnya dapat terlepas dari kekufuran.

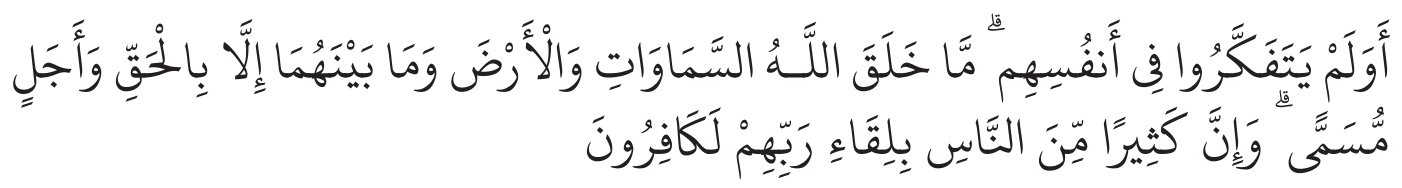

Dan mengapa mereka tidak memikirkan tentang (kejadian) diri mereka? Allah tidak menjadikan langit dan bumi dan apa yang ada diantara keduanya melainkan dengan (tujuan) yang benar dan waktu yang ditentukan. Dan sesungguhnya kebanyakan di antara manusia benar-benar ingkar akan pertemuan dengan Tuhannya. (QS al-Rum [30] 8).

Alam semesta merupakan realitas yang memang manusia hidup di dalamnya. Meski ilmu pengetahuan sudah dikembangkan dengan demikian hebatnya, akan tetapi tetap saja rahasia alam semesta masih banyak yang belum terungkap. Maka dari itu, manusia dianjurkan untuk terus melakukan penelitian serta pengkajian, sehingga berbagai misteri alam semesta dapat disingkapkan. Bagi seorang ilmuwan yang beriman, tentu ia menyadari bahwa ilmu pengetahuan yang dikembangkan bukanlah untuk menaklukkan kedigdayaan alam semesta. Melainkan untuk mencari ridha Allah SWT. Ketika ia menemukan banyak penemuan ilmiah, maka keimanannya pun akan senantiasa bertambah. Imam Syafi'i pernah berkata: "setiap aku bertambah ilmu, maka aku tahu juga kebodohanku." Ungkapan ini merefleksikan bagaimana sejatinya seseorang yang memiliki akal. Ketika ia berpikir dan menemukan hal-hal baru hasil dari olah pikirnya itu, maka ia akan semakin dekat dengan kesadaran bahwa dirinya itu bodoh dan hanya Allahlah yang Maha Mengetahui. ${ }^{6}$

Jadi al-Qur'an memerintahkan manusia untuk memaksimalkan akal mereka dalam mempelajari alam semesta bertujuan untuk mengetahui tanda-tanda

${ }^{6}$ HM Rasjidi dan Drs. H. Harifuddin Cawidu, Islam untuk Disiplin Ilmu Filsafat, hal, 19. 
kekuasaan Allah dan berbagai rahasia yang terkandung di dalamnya. Allah berfirman di dalam Surat al-Dzariyat ayat 20 - 22:

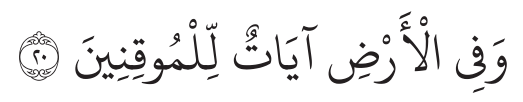

"Dan di bumi itu terdapat tanda-tanda (kekuasaan Allah) bagi orangorang yang yakin."

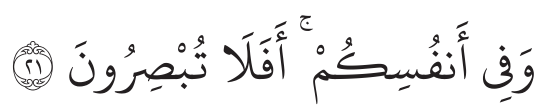

"dan (juga) pada dirimu sendiri. Maka apakah kamu tidak memperhatikan?"

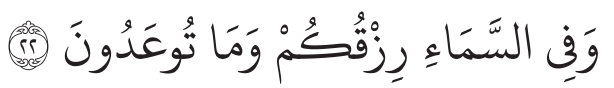

"Dan di langit terdapat (sebab-sebab) rezekimu dan terdapat (pula) apa yang dijanjikan kepadamu."

Nampak jelas dari ketiga ayat tersebut bahwa seseorang yang berpikir pasti akan dipenuhi kebutuhan (rizki) hidupnya dan apa-apa yang telah Allah janjikan.

Demikianlah sepintas ayat-ayat al-Qur'an yang mendorong umat manusia untuk memaksimalkan akal yang mereka miliki. Dan telah terbukti dalam sejarah Islam, ketika umat Islam terus aktif memaksimalkan penggunaan akal, maka kemajuan peradaban Islam pun dapat teraih. Berbagai temuan ilmiah berhasil dicapai. Dan umat Islam pun menjadi umat yang disegani oleh bangsa-bangsa lain dikarenakan kepandaian umat Islam di dalam mengembangkan ilmu pengetahuan dan teknologi dan pada saat yang bersamaan terus menjaga api iman yang dimiliki oleh individu masing-masing.

\section{Kedudukan Akal di Dalam Hadits Nabi}

Jika akal begitu diagungkan di dalam al-Qur'an, bagaimana dengan Hadits, apakah akal memiliki kedudukan yang juga istimewa? Jika memang demikian, akal yang bagaimanakah yang menduduki posisi istimewa dalam perspektif hadis?.

Sebagaimana diketahui bersama bahwa hadis merupakan salah satu warisan yang diberikan oleh Rasulullah SAW. Sebagai pengulas al-Qur'an, posisi hadis sangatlah penting. Allah berfirman di dalam Surat al-Nisa ayat 26: 


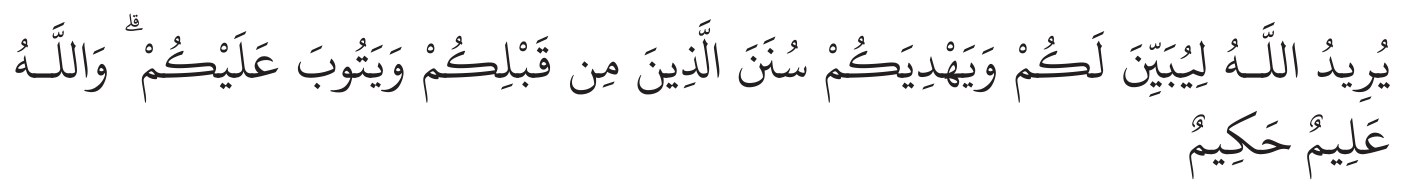

"Allah hendak menerangkan (hukum syariat-Nya) kepadamu, dan menunjukimu kepada jalan-jalan orang yang sebelum kamu (para nabi dan shalihin) dan (hendak) menerima taubatmu. Dan Allah Maha Mengetahui lagi Maha Bijaksana." (QS al-Nisa [4] 26).

Menurut Imam Qurtubi, ayat ini memberikan petunjuk mengenai tata cara hidup orang saleh sebelum Nabi Muhammad. Ada yang berpendapat bahwa memberikan petunjuk di situ berarti menerangkan tata cara orang-orang sebelum Nabi Muhammad. Bahkan menurut Ibn Katsir, kata "sunan" di situ berarti tata cara yang baik dan terpuji dari orang-orang sebelum Nabi yang telah mengikuti syariat Allah. ${ }^{7}$ berikut: ${ }^{8}$

Hadits atau Sunnah di dalam Islam memiliki tugas dan peran sebagai

1. Hadits berfungsi sebagai penjelas dari al-Quran al-Karim

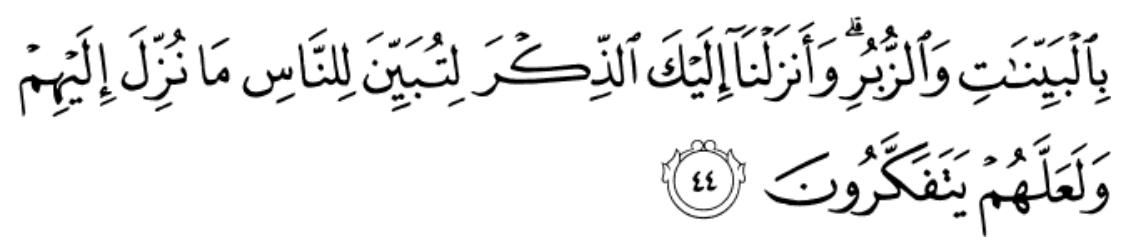

"keterangan-keterangan (mukjizat) dan kitab-kitab. Dan Kami turunkan kepadamu Al Quran, agar kamu menerangkan pada umat manusia apa yang telah diturunkan kepada mereka dan supaya mereka memikirkan." (QS al-Nahl [16] 44).

2. Rasulullah merupakan tauladan baik yang wajib dicontoh setiap umat Islam

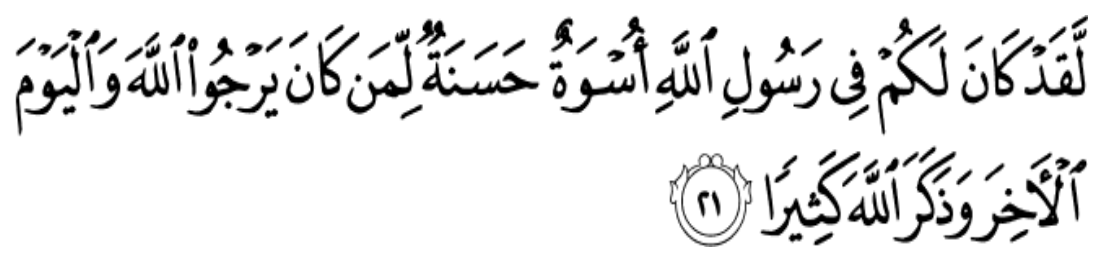

${ }^{7}$ M.M. Azami. Hadis Nabawi dan Sejarah Kodifikasinya, hal, 13.

${ }^{8}$ M.M. Azami. Hadis Nabawi dan Sejarah Kodifikasinya, hal, 27. 
Sesungguhnya telah ada pada (diri) Rasulullah itu suri teladan yang baik bagimu (yaitu) bagi orang yang mengharap (rahmat) Allah dan (kedatangan) hari kiamat dan dia banyak menyebut Allah. (QS al-Ahzab [33] 21).

3. Rasulullah SAW Wajib ditaati

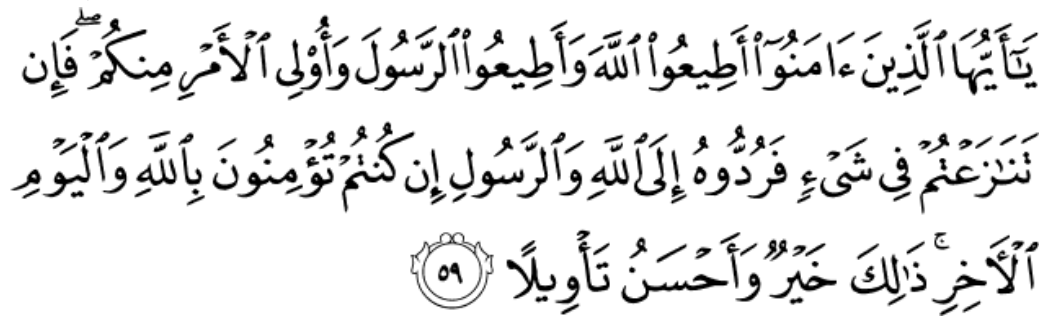

Hai orang-orang yang beriman, taatilah Allah dan taatilah Rasul (Nya), dan ulil amri di antara kamu. Kemudian jika kamu berlainan pendapat tentang sesuatu, maka kembalikanlah ia kepada Allah (Al Quran) dan Rasul (sunnahnya), jika kamu benar-benar beriman kepada Allah dan hari kemudian. Yang demikian itu lebih utama (bagimu) dan lebih baik akibatnya. (QS al-Nisa [4] 59)

4. Rasulullah SAW Mempunyai Wewenang untuk Membuat Suatu Aturan

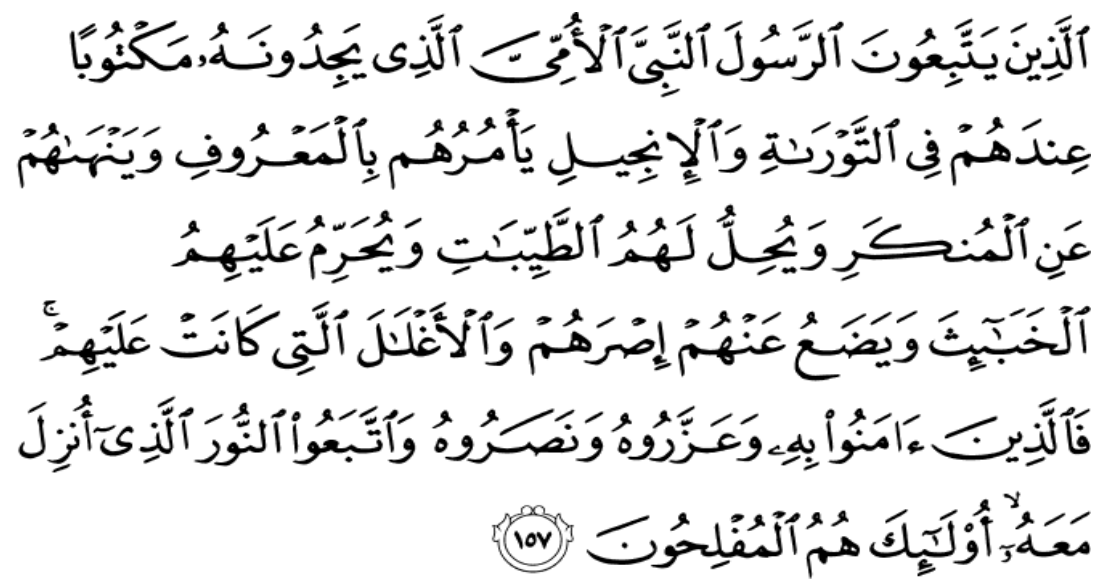

(Yaitu) orang-orang yang mengikut Rasul, Nabi yang ummi yang (namanya) mereka dapati tertulis di dalam Taurat dan Injil yang ada di sisi mereka, yang menyuruh mereka mengerjakan yang ma'ruf dan melarang mereka dari mengerjakan yang mungkar dan menghalalkan bagi mereka segala yang baik dan mengharamkan bagi mereka segala yang buruk dan membuang dari mereka beban-beban dan belenggu-belenggu yang ada pada mereka. Maka orang-orang yang beriman kepadanya. memuliakannya, menolongnya dan mengikuti cahaya yang terang yang diturunkan 
kepadanya (Al Quran), mereka itulah orang-orang yang beruntung. (QS al-'Araf [7] 157).

Maka dari itu hadits Nabi atau Sunnah juga merupakan wahyu sebagaimana al-Qur'an itu sendiri adalah wahyu. ${ }^{9}$ Allah berfirman di dalam al-Qur'an:

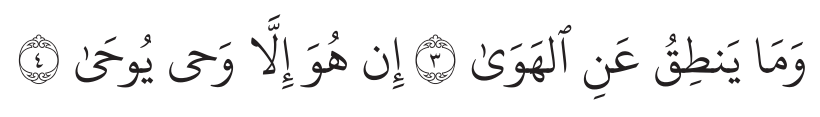

dan tiadalah yang diucapkannya itu (Al-Quran) menurut kemauan hawa nafsunya Ucapannya itu tiada lain hanyalah wahyu yang diwahyukan (kepadanya) (QS al-Najm [53] 3-4).

Jelaslah di sini bahwa hadits Nabi memiliki posisi dan penting dalam menjelaskan maksud-maksud dalam al-Quran, sehingga umat Islam yang datang kemudian dapat mencontoh kiprah Nabi Muhammad semasa hidupnya. Lantas, bagaimana Hadits sendiri memandang akal? Apakah ada kriteris khusus atau rambu-rambu yang hendaknya dipegang manusia sebelum menggunakan akalnya?

Di dalam hadits Nabi banyak uraian mengenai akal, khususnya bila dikaitan dengan perkembangan ilmu pengetahuan. Berikut ini beberapa hadits Nabi yang mengulas mengenai akal serta berbagai fungsinya.

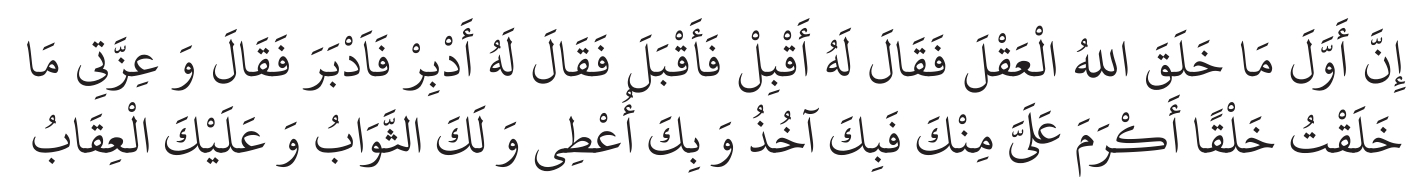

"Sesungguhnya yang pertama-tama Allâh ciptakan adalah akal. Allâh berkata kepadanya, 'datang menghadaplah!'. Maka iapun datang menghadap. Allâh berkata kepadanya, 'mundurlah ke belakang!'. Maka iapun mundur ke belakang. Lalu Allâh berfirman, 'Demi kemuliaan-Kû, Akû tidaklah menciptakan makhluk yang lebih mulia darimu atas-Kû. Dengan sebabmulah Akû menyiksa, dengan sebabmulah Akû memberi, bagimulah pahala dan atasmulah hukuman."

Dalam Hadits, Rasulullah SAW menjunjung tinggi akal sampai-sampai dikatakan bahwa seseorang dianggap tidak beragama manakala tidak memiliki akal di dalamnya. Nabi Muhammad SAW bersabda, sebagaimana diuraikan di dalam Kitab Ihya 'Ulum al-Din, bahwa "orang alim itu adalah orang kepercayaan

${ }^{9}$ Muhammad Abu Zahw. The History of Hadits: Historiografi Hadits dari Masa ke Masa (Depok: Keira Publishing, 2015), hal. 1-3. 
Allah di bumi-Nya" lebih dari itu "pada hari kiamat nanti yang memberi syafaat adalah nabi-nabi, para ulama kemudian para syuhada"'. ${ }^{10}$

Nabi Muhammad SAW bersabda ketika mengutus Muadz ke Yaman: "Petunjuk yang diberikan Allah kepada seseorang dengan perantaraanmu lebih baik bagimu daripada dunia dan segala isinya." Umar RA berkata: "Barangsiapa menceritakan sebuah hadits, lalu diamalkan, maka ia mendapat pahala seperti pahala amal itu.". Muadz bin Jabal berkata mengenai pengajaran dan meriwayatkannya" Belajarlah ilmu, karena mempelajari ilmu karena Allah adalah kebaikan dan menuntut ilmu adalah ibadah, pengkajiannya seperti sebuah tasbih, penyelidikannya seperti jihad, pengajarannya adalah shodaqah dan pemberiannya kepada ahlinya adalah pendekatan diri kepada Allah SWT. Ilmu adalah penghibur di kala kesepian, teman di waktu menyendiri dan petunjuk di kala senang dan susah. Ia adalah pembantu dan teman yang baik dan penerang jalan ke surga. ${ }^{11}$

\section{Catatan Kritis}

Jika diteliti lebih jauh posisi akal atau anjuran penggunaan akal di dalam Hadits memiliki banyak ragam penjelasan, setidaknya ada dua kelompok pemahaman yang terjadi:

1. Hadits Nabi sangat menganjurkan kita berpikir apa saja, sampai-sampai seseorang dikatakan tidak beragama ketika tidak memiliki akal.

2. Hadits lain ada yang mengatakan boleh seseorang berakal akan tetapi harus mempertimbangkan jangan sampai akal dipakai untuk berpikir tentang zat Allah karena akal tidak akan sanggup, cukup bagi akal digunakan untuk berpikir tentang makhluk Allah atau ciptaan-Nya saja.

3. Terjadi juga ikhtilaf ulama, khususnya terkait dengan hadits:

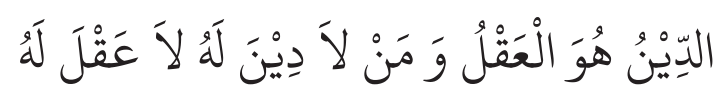

"Agama itu adalah akal, dan seseorang itu tiada agama baginya yang tidak ada akal baginya."

Menurut Asy-Syaikh Al-Albaniy, hadis ini bertentangan dengan hadis yang lainnya bahkan hukumnya bathil. Hal yang sama juga disampaikan An-Nasa'iy di dalam kitab "Al-Kunya" dan Ad-Dulabiy di dalam kitab "Al-Kunya wa Al-Asma”. Berkata An-Nasa'iy, "Ini adalah hadits bathil Munkar.” Telah mengeluarkan (hadits ini pula) Al-Harits bin Abu Usamah di dalam Mus-

\footnotetext{
${ }^{10}$ Imam al-Ghozali. Mukhtashar Ihya Ulumuddin (Jakarta: Pustaka Amani, 1986), hal. 9.

${ }^{11}$ Imam al-Ghozali. Mukhtashar Iha Ulumuddin, hal. 326.
} 
nad-nya dari Dawud bin Al-Muhabbir sekitar 39 hadits mengenai keutamaan akal. Berkata Al-Hafizh Ibnu Hajar, Semuanya Maudlu' (palsu). Berkata Asy-Syaikh Al-Albaniy, "Termasuk dari baiknya tanbih (peringatan) adalah bahwasanya semua hadits yang datang mengenai keutamaan akal adalah tidak shahihsedikitpun darinya yaitu berkisar antara lemah dan palsu."

4. Bahkan terdapat hadits lain yang disampaikan Rasulullah sebagai berikut:

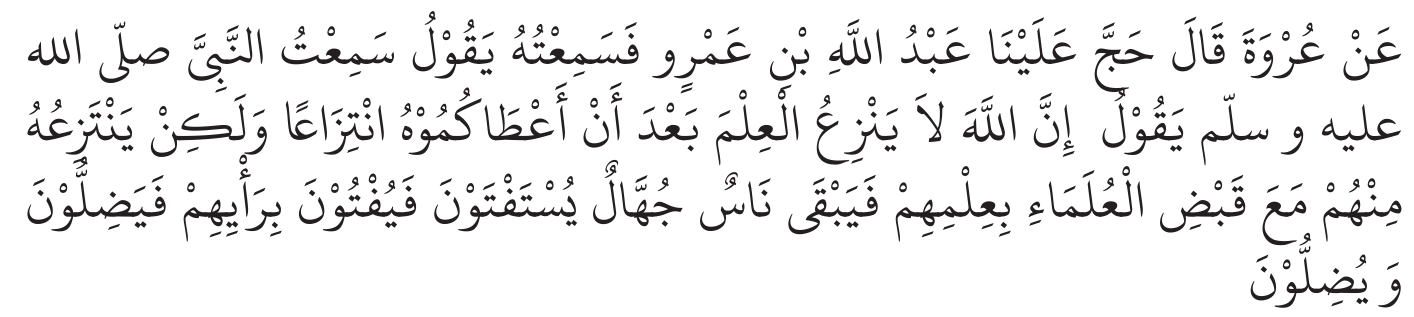

"Dari 'Urwah (bin Az-Zubair) berkata, "Pernah berhajji atas kami Abdullah bin 'Amr, lalu aku mendengarnya berkata, "Aku pernah mendengar Nabi Shalallâhu <alaihi wa sallam bersabda, "Sesungguhnya Allâh tidak akan mencabut ilmu itu sesudah memberikannya kepada kalian dengan sekali cabut. Tetapi Iâ akan mencabutnya dari mereka disertai wafatnya ulama (para orang alim) dengan membawa ilmu mereka. Lalu tinggallah beberapa orang bodoh yang diminta fatwa, lalu mereka berfatwa dengan raıyu (pendapat) mereka, maka mereka sesat dan menyesatkan." ${ }_{12}^{\prime \prime}$

Demikianlah hadits lain yang berpendapat bahwa penggunaan ra'yu (akal) yang terlalu berlebihan dapat membawa kepada kesesatan dan bahkan menyesatkan.

Sebagai kesimpulan, penggunaan akal di dalam hadis sangat dianjurkan akan tetapi kadar pengunaannya itulah yang harus ditakar dan ada batasannya. Jangan sampai lahir cara berpikir yang mutlak dan absolut yang kelak akan mengancurkan manusia itu sendiri. Memang betul dalam sejarah Islam, dulu pernah lahir umat Islam yang memaksimalkan cara berpikirnya, tapi harus jadi catatan bahwa mereka senantiasa berpikir dan berdzikir bersamaan guna mencari ridlaAllah SWT. Allahu a'lamu bi al-Shawwab.

${ }^{12}$ Lihat Imam Bukhari, Shahih Bukhari (Beirut: Dar al-Manshurah, T,tp), vol 9, hal, 100. 


\section{Daftar Pustaka}

Abu, Muhammad Zahw. The History of Hadits: Historiografi Hadits dari Masa ke Masa. Depok: Keira Publishing, 2015.

Bukhari, Imam. Shahih BukhariBeirut: Dar al-Manshurah, T,tp.

Hossein, Seyyed Nasr \& Oliver Leaman (ed.). Ensiklopedi Filsafat Islam. Bandung: Mizan, 2003.

M.M. Azami. Hadis Nabawi dan Sejarah Kodifikasinya, Jakarta: Pustaka Firdaus, 2000.

Muhammad, Abu al-Ghozali. Mukhtashar Iha Ulumuddin. Jakarta: Pustaka Amani, 1986.

Rasjidi, HM dan H. Harifuddin Cawidu. Islam untuk Disiplin Ilmu Filsafat. Jakarta: Bulan Bintang, 1988. 